\title{
Compliment-giving Behavior in American English and Japanese
}

\author{
Hiroko Matsuura \\ Fukushima University
}

This study explores how the perceived likelihood of giving compliments differs between Americans and Japanese: that is, those who are said to belong to Brown \& Levinson's positive politeness and negative politeness cultures, respectively. The results of the detailed analyses of a survey of 44 American and 44 Japanese university students suggest four major differences in complimentgiving behaviors. First, the distinction between $u c h i$ and soto affects Japanese compliment-giving behaviors, as Japanese tend to be less polite toward family members in general. This is probably a more influential factor for Japanese than the categories of close and distant, which is highly influential for Americans (the closer the relationship to the addressee, the more willing Americans are to give compliments). Second, the influence of gender difference on the likelihood of complimenting others is greater for Americans than for Japanese. Third, psychological closeness sometimes overrides status and power differences in the compliment-giving behaviors of Japanese, while status and power tend to prevent Americans from complimenting higher-status addressees. Lastly, Americans appear to believe that complimenting someone is relatively easy, while Japanese tend to think complimenting is more difficult.

アメリカ人と日本人がほめ行動を起こす可能性の度合いについて比較した。彼らは、ブ ラウン\&レビンソンの唱える積極的ポライトネス文化と消極的ポライトネス文化にそれぞ れ属すると言われている。日米各44名の大学生を対象として質問紙による調査を実施した ところ、以下の $4 \supset か ゙$ 相違点として浮かび上がった。一点目は、アメリカ人のほめ行動で は対話者間の親疎関係がほめの出現に影響を及ぼしていたのに対して、日本人ではウチ・ ソトの区別が強い影響力を持っているということである。一般的に日本人は家族に対して 丁寧ではないが、アメリカ人は対話者との距離が近いほど相手をほめようとする傾向が強

JALT Journal, Vol. 26, No. 2, November, 2004 
くなる。二点目は、ほめ行動を起こす可能性の男女差はアメリカ人のほうが日本人に比べ て大きいことが挙げられる。三点目は、アメリカ人のほめにおいては相手の地位や力がそ の行為を妨げる要因となりがちであるが、日本人の場合は相手との精神的距離が地位や力 関係に優ることがあるという点である。最後に、アメリカ人は相手をほめることは比較的 たやすいことであると感じる一方で、日本人はほめを難しいものと考える傾向があった。

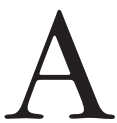
s Brown and Levinson (1987) claim, giving compliments is an important politeness strategy which functions as a social lubricant in almost every part of the world. However, people from different cultural backgrounds might perceive the illocutionary force of complimentary acts somewhat differently. According to Brown and Levinson's (1987) dichotomous categorization of positive politeness and negative politeness, whereas Americans are considered to be in the spectrum of a more positive politeness culture, Japanese are in a more negative politeness culture. The authors claim that positive politeness is approach-based and is oriented toward maintaining the positive face of the hearer, (i.e., the positive self-image that s/he claims for her/himself). Therefore, the speaker says what she/he believes the hearer wants to hear. Giving a compliment is a good example of a positive politeness strategy (e.g., "I like your hair"). Negative politeness, on the other hand, is avoidance-based, and it is oriented toward satisfying the hearer's negative face, (i.e., her/his basic desire to maintain territorial claims). Thus, when asking for a favor, this type of speaker will try not to interfere with the hearer's freedom by attempting to minimize the imposition arising from the request (e.g., "I just want to ask you if I can borrow a tiny bit of paper"). Based on these two categorizations, this study posits that Americans and Japanese in fact do perceive the illocutionary force of compliments differently, and that their likelihood of making compliments in their native languages differs accordingly. This study is an attempt to explore the cultural differences that Americans and Japanese display when giving compliments.

\section{Previous studies on compliments}

There is abundant research available dealing with English compliments, most of which is centered on the investigation of linguistic forms, relationships between compliment givers and receivers, and the targets of compliments. Manes and Wolfson (1981) reported interesting findings on the linguistic forms of compliments. They analyzed a compliment corpus of 686 expressions and found that compliments are formulaic. In 
their data, $85 \%$ of compliment expressions fell into one of the following three syntactic formulae:

(1) NP is/looks (really) ADJ (e.g., "That shirt is so nice.");

(2) I (really) like/love NP (e.g., "I really like those shoes."); and

(3) $P R O$ is (really) (a) ADJ NP (e.g., "This was really a great meal.").

Wolfson (1983) further discovered that two-thirds of all adjectival compliments she had collected made use of only five adjectives: nice (22.9\%), good (19.6\%), pretty (9.7\%), beautiful (9.2\%), and great (6.2\%).

These findings encouraged other researchers to conduct similar surveys on compliment-giving behavior. For example, Holmes (1988) replicated the syntactic formulae of compliments that Manes and Wolfson (1981) had made and discovered that $78 \%$ of compliment occurrences in New Zealand English had one of the three patterns that had been reported for American English. Moreover, the author noted that four out of the five adjectives most frequently used in compliments in New Zealand were in Wolfson's (1983) top five, nice, good, beautiful, and great. As indicated by Manes and Wolfson (1981), Wolfson (1983), and Holmes (1988), compliments in English are formulaic both in terms of syntax and semantics and are therefore easily identifiable and distinguishable from other statements in streams of speech (Knapp, Hopper, \& Bell, 1984).

Knapp et al. (1984) examined complimentary acts more extensively from a variety of angles and succeeded in identifying several features of American compliments. Some of these findings were that the American compliments in their data referred mostly to someone's appearance/attire and performance (i.e., abilities and skills), and that lower percentages of compliments referred to personality and possessions. American compliments tended to be stated directly (e.g., "I think you do really nice work") and generally (e.g., "You look nice") rather than indirectly (e.g., "Professor Keller said you do really nice work") and specifically (e.g., "You look nice in that tie"). The majority of compliments were also made without comparing the hearer to others (e.g., "You look young" as opposed to "You look years younger than your little brother"). Moreover, American compliments were more often delivered to the addressee by an interlocutor of the same sex, similar age, and equal status.

Since then, compliments have often been selected as a target of crosscultural investigation, not only between different varieties of the same 
language (Creese, 1991) but also across different languages (Barnlund \& Araki, 1985; Daikuhara, 1986; Lewandowska-Tomaszczyk, 1989; Nelson, et al., 1993; Matsuura, 2004; Ylänne-McEwen, 1993). With respect to English and Japanese compliments, Barnlund and Araki (1985) were forerunners, using interviews and a questionnaire to obtain data for contrastive analyses. Strikingly, incidents of complimentary acts reported by Americans occurred within the short period of the previous 36 hours on the average, whereas incidences of compliments reported by Japanese occurred on average within the previous 312 hours (13 days)-suggesting that Americans tend to give compliments more often than Japanese do. The results of the 1985 questionnaire also suggested that Americans, particularly those in close relationships, were likely to exchange compliments far more often than Japanese, whereas Japanese were observed to exchange compliments less frequently in close relationships and more often in distant relationships.

The study by Barnlund and Araki (1985) as a whole was successful in identifying some interesting cross-cultural differences between American and Japanese compliments. However, there appear to be at least two points that should be considered in more depth: relative power status and addressee gender. Barnlund and Araki did not clearly explain status relations between compliment givers and receivers. In addition, they failed to consider how genders of both interlocutors affect the frequency of compliments. This poses several questions as to whether, for example, American females would give compliments to other females in their culture more often than Japanese females would within their own culture (the same could be asked about men). It would be interesting to investigate gender effects of both sides more deeply, since earlier studies (e.g., Knapp et al., 1984) have pointed out that the genders of both compliment givers and receivers appear to influence the frequency of compliments.

Following Barnlund and Araki (1985), other researchers have conducted contrastive analyses on compliment-giving behaviors. Daikuhara (1986), who also analyzed Japanese and American compliments, left similar issues unexplained because of the nature of her study. Most of her data were analyzed qualitatively, and therefore the frequencies of compliments depending on status and gender relations were not noted. Nelson, El Bakary, and Al Batal (1993) investigated Egyptian and American compliments. In collecting data, they used interviews and a questionnaire, both of which were similar to those of Barnlund and Araki (1985). The 1993 study was generally more successful because of more 
elaborate analyses that incorporated the genders of both compliment givers and receivers as independent variables. However, they did not explore how status affected compliment-giving behaviors.

The counterpart to a compliment is the compliment response, which has been investigated across cultures since the late 1980s (e.g., Chen, 1993; Golato, 2002; Han, 1992; Herbert, 1989; Herbert \& Straight, 1989; Lewandowska-Tomaszczyk, 1989; Lorenzo-Dus, 2001; Matsuura, 2002; Nelson, Al-Batal, \& Echols, 1996; Saito \& Beecken, 1997). Among those studies of cross-cultural comparison, Matsuura (2002) is one of the few studies that illustrates differences between American and Japanese response patterns, and suggests that ostensible acceptance, or light acceptance, of compliments may be characteristic of American English. An ostensible acceptance is considered to be the counterpart to an ostensible compliment-an act that is mainly performed for the sake of politeness and is claimed by Clark (1996) to be a kind of act not to be taken seriously. American respondents in Matsuura's (2002) study reacted differently to appearance-related compliments and compliments given on performance or skills. To the former types of compliments, regardless of the gender or status of the compliment givers, Americans responded mainly by using appreciation tokens (e.g., "Thank you") with the occasional comment history (e.g., "I bought it yesterday"). Yet with respect to ability-related compliments, they revealed diverse response styles that depended on the illocutionary force of the particular compliments they perceived. Japanese, on the other hand, tended to use wider varieties of responses in both appearance- and ability-related situations, which suggests that they had a tendency to take compliments on appearance a little more seriously than their American counterparts.

This study compares American and Japanese speakers' likelihood of giving compliments to various addressees of different psychological distances and various levels of power in corresponding native language speaking situations. Compliments dealt with in this study are solely appearance-related, that is, compliments on other people's attire, haircuts, fashion accessories, and so forth. The results of an earlier study of compliment responses (Matsuura, 2002) suggested that Americans and Japanese react quite differently to this type of compliment. This study attempts to probe more deeply the question of whether speakers of American English and those of Japanese perceive the illocutionary force of appearance-related compliments quite differently, focusing on perceptual differences between Americans and Japanese regarding compliment-giving behavior. 
The first research question this study examines is (1) how the gender, status, and psychological distance of the addressee affect the likelihood of giving compliments in American and Japanese cultures. Another research question is (2) whether Americans are more likely to exchange compliments than Japanese. Specifically, are American females more likely to give compliments to other females in the same culture as compared to their Japanese counterparts? Are American males more likely to give compliments to other males in the same culture than their Japanese counterparts? Are American or Japanese females more likely to give compliments to males of the same culture? And are American or Japanese males more likely to give compliments to females of the same culture? Finally, the study intends to explore (3) the general ideas that Americans and Japanese hold about complimenting and how they differ.

\section{Method}

Participants

The participants of this study were: 1) 44 native English-speaking students from various academic fields at a university in the eastern part of the U.S.A.; and 2) 44 Japanese university students, all of whom were native Japanese speakers majoring in economics at a university in northeastern Japan. Earlier studies on compliments in English pointed out that both interlocutors' ages were a significant factor in the use of compliments (e.g., Knapp et al., 1984). Therefore, assuming that some control over age would be indispensable, the investigator decided to recruit only undergraduate students for this study. The average age of the American participants was 20.27 with a range of 18 to 25. Japanese ages were from 18 to 23 with an average of 19.86. Both language groups consisted of 22 males and an equal number of females.

Participation in this survey was completely voluntary. The questionnaire was distributed in classrooms in both countries. The American students either answered it at home or filled it out in classes, whereas the Japanese students completed the questionnaire during the last 10 minutes of a 90-minute English class. Initially, more than 50 volunteers from each culture submitted their questionnaires. However, as several of these respondents were older (over the age of 25) and/or international students, the investigator decided to exclude their data. This process left only 22 American males and well over 22 students from the remaining respondent groups. The size of each participant group was thus determined as 22. Participants in the American female, the Japanese male, 
and the Japanese female groups were randomly selected from among the remaining volunteers.

\section{Questionnaire design}

The investigator developed a Likert-scale type questionnaire (see Appendix) in English, which was subsequently translated into Japanese. To assure that the Japanese translation was accurate, a bilingual EFL instructor (a native Japanese speaker) back-translated it into English, and all discrepancies were clarified. The participants were then given the version written in their native languages. The questionnaire contained 30 items, among which 20 were intended to elicit the likelihood of students giving compliments in various given contexts. The first part of the questionnaire consisted of brief statements each describing a situation in which a compliment could be made and asked participants to rate on a seven-point rating scale whether they would offer compliments. Participants were asked to read the statements and indicate the extent to which they would give compliments to either male or female addressees of various social statuses. Among the first 20 questionnaire items, 16 were designed to elicit the likelihood of offering compliments on others' appearance, and four were distracters in which compliments on ability or skills were elicited. These four items were thus excluded from analysis.

The social status and power of the addressees were deliberately set so that respondents would be confronted with scenarios involving various psychological distances and differing levels of social power. With regard to psychological distance, two types of distinction were included. One type was close (e.g., a close friend) vs. distant (e.g., a classmate whom the participant barely knows). The other type involved the Japanese concept of $u c h i$ (inside) and soto (outside). While Japanese are able to draw a line between $u c h i$ and soto everywhere according to perceived social and psychological distance between themselves and other people (Bachnik, 1994), family members enjoy permanent miuchi (insiders) status. Family members were included as addressees in this study because the Japanese distinction of $u c h i$ and soto is particularly influential in establishing levels of politeness in the language-that is, there is less need to be polite to or to compliment family members. The questionnaire also incorporated three distinct status categories: higher (e.g., an academic advisor), equal (e.g., a classmate), and lower (e.g., a junior member of a club to which the participant belongs). Addressees were the types of people university students of both nationalities might encounter in everyday situations: par- 
ents, classmates, and academic advisors. Moreover, interlocutors' genders were given because gender is regarded as another important factor in giving compliments (Knapp et al., 1984; Herbert, 1990). In the questionnaire, the addressees' genders were presented as either "the same sex" or "the opposite sex" rather than usual "male" and "female" in order to be relative to the gender of the respondents.

The second part of the questionnaire was intended to elicit respondents' beliefs about complimenting. It specifically asked when and why participants offered compliments in their native language speaking situations. For this purpose, a Likert scale was employed along with nine statements, including "I compliment someone because I really want to make him/her happy," "Complimenting is a good way to start a conversation," and "It is easy for me to make small compliments." The very last questionnaire item was open-ended and was designed to elicit reasons not presented in the nine statements above. At the end of the questionnaire was the section in which students' personal profile was elicited: their gender, age, major, and experience living abroad.

\section{Analysis}

To examine overviews of American and Japanese willingness to give compliments to addressees of various social and psychological distances, averages of respondent ratings were calculated for each of the 16 questionnaire items in the first section. Then, one-way ANOVAs (analyses of variance) were used to see how American and Japanese ratings would differ according to the status and psychological distances of the addressees. Another one-way ANOVA was employed to investigate the extent to which American and Japanese ratings differed along four different gender sets of interactional scenarios: male to male, male to female, female to female, and female to male. In the second part of the questionnaire, frequencies and averages of ratings were counted so as to explore cultural differences in beliefs about reasons for performing complimentary acts.

\section{Limitations}

This study is exploratory in nature. Unlike Barnlund and Araki's (1985) study, in which participants were asked to recall and report compliment-giving situations they were actually involved in, this study is highly hypothetical. As explained above, the participants' likelihood to 
compliment in this study was elicited by means of a Likert-type questionnaire. This means that what respondents indicated they are likely to do in a given context may not always coincide with what they would actually do when they are later involved in a situation similar to the one in the questionnaire. This is one limitation of this study. Another limitation is that the participants in the study were not randomly selected; they were convenience samples drawn exclusively from universities with which the investigator is acquainted. Their behavior, thus, may not be representative of the cultures to which they belong.

Though the paper-and-pencil type of questionnaire has limitations, it permitted the investigator to control compliment-giving contexts (e.g., what are the compliment receiver's gender, age, and occupation? what is the attribute?). This type of survey also allows the investigator to access fairly homogeneous respondent groups (age, gender, and occupation) of considerable size.

\section{Results}

Table 1 shows that American and Japanese average ratings for complimenting differed from situation to situation. As their averages indicate, American respondents tended to perceive that boyfriends or girlfriends were most likely to receive compliments (Item 3), and family members followed boyfriends or girlfriends (Items 6, 20, 15, and 14). Addressees with other close relationships were next (Items 1, 7, 8, and 10). Those most distant were least likely to receive compliments. This is reflected in the average ratings toward them, which were lower than the neutral 4.00 on the seven-point scale (Items 9, 18, 2, 16, 5, and 12).

Likewise, in the Japanese data, boyfriends and girlfriends were perceived to be most likely to receive compliments. However, unlike the American English speakers, Japanese respondents were less likely to indicate they would give compliments to family members more often than to other close addressees. Another notable difference between Japanese and Americans can be seen in Item 11, where the addressee was a young seminar instructor. The Japanese average was 4.59, which suggests that many of them were not likely to hesitate to compliment classroom instructors. The American average of 3.23 on Item 11, on the other hand, implied that many of the respondents were rather reluctant to praise their instructors.

American ratings were significantly higher than Japanese in complimenting family members, whereas no significant cultural differences 
Table 1. Likelihood of Giving Compliments According to Addressee Type

\begin{tabular}{rccccc}
\hline Item & $\begin{array}{c}\text { Americans' } \\
\text { relationships }\end{array}$ & Mean & Item & $\begin{array}{c}\text { Japanese } \\
\text { relationships }\end{array}$ & Mean \\
\hline 3 & $\mathrm{C}+\mathrm{E}+\mathrm{O}$ & 6.86 & 3 & $\mathrm{C}+\mathrm{E}+\mathrm{O}$ & 6.68 \\
6 & $\mathrm{U}-$ mother & 6.52 & 10 & $\mathrm{C}+\mathrm{L}+\mathrm{O}$ & 5.66 \\
20 & $\mathrm{U}+\mathrm{L}+\mathrm{S}$ & 6.23 & 1 & $\mathrm{C}+\mathrm{E}+\mathrm{S}$ & 5.27 \\
15 & $\mathrm{U}+\mathrm{L}+\mathrm{O}$ & 6.11 & 7 & $\mathrm{C}+\mathrm{H}+\mathrm{S}$ & 5.11 \\
14 & $\mathrm{U}-$ father & 6.09 & 15 & $\mathrm{U}+\mathrm{L}+\mathrm{O}$ & 5.09 \\
1 & $\mathrm{C}+\mathrm{E}+\mathrm{S}$ & 5.59 & 8 & $\mathrm{C}+\mathrm{L}+\mathrm{S}$ & 5.02 \\
7 & $\mathrm{C}+\mathrm{H}+\mathrm{S}$ & 5.41 & 20 & $\mathrm{U}+\mathrm{L}+\mathrm{S}$ & 5.00 \\
8 & $\mathrm{C}+\mathrm{L}+\mathrm{S}$ & 5.30 & 6 & $\mathrm{U}-\mathrm{mother}$ & 4.95 \\
10 & $\mathrm{C}+\mathrm{L}+\mathrm{O}$ & 4.91 & 14 & $\mathrm{U}-\mathrm{father}$ & 4.77 \\
9 & $\mathrm{D}+\mathrm{L}+\mathrm{O}$ & 3.86 & 11 & $\mathrm{C}+\mathrm{H}+\mathrm{O}$ & 4.59 \\
18 & $\mathrm{D}+\mathrm{L}+\mathrm{S}$ & 3.66 & 18 & $\mathrm{D}+\mathrm{L}+\mathrm{S}$ & 3.57 \\
11 & $\mathrm{C}+\mathrm{H}+\mathrm{O}$ & 3.23 & 9 & $\mathrm{D}+\mathrm{L}+\mathrm{O}$ & 3.55 \\
2 & $\mathrm{D}+\mathrm{E}+\mathrm{O}$ & 3.11 & 5 & $\mathrm{D}+\mathrm{E}+\mathrm{S}$ & 3.48 \\
16 & $\mathrm{D}+\mathrm{H}+\mathrm{S}$ & 2.98 & 12 & $\mathrm{D}+\mathrm{H}+\mathrm{O}$ & 3.36 \\
5 & $\mathrm{D}+\mathrm{E}+\mathrm{S}$ & 2.91 & 16 & $\mathrm{D}+\mathrm{H}+\mathrm{S}$ & 3.23 \\
12 & $\mathrm{D}+\mathrm{H}+\mathrm{O}$ & 2.50 & 2 & $\mathrm{D}+\mathrm{E}+\mathrm{O}$ & 2.98 \\
\hline
\end{tabular}

Distance: Status: Gender:

$\mathrm{U}=$ uchi $\quad \mathrm{L}=$ lower $\quad \mathrm{S}=$ same

$\mathrm{C}=$ close $\quad \mathrm{E}=$ equal $\quad \mathrm{O}=$ opposite

$\mathrm{D}=$ distant $\mathrm{H}=$ higher

were detected in other categories of people: that is, compliment receivers with close relationships (excluding family members) and those with distant relationships. This was observed in Items 6, 14, 15, and 20, where interlocutors were family members, and where the American average was 6.24 compared with 4.95 for the Japanese. And in the results of a one-way ANOVA, the two group averages were found to be different at a significant level $[F(1,86)=19.05, p<.001]$. On the other hand, the American and Japanese average response ratings toward people in other close relationships (Items 1, 3, 7, 8, 10, and 11) were 5.21 and 5.39, and were not significantly different $[F(1,86)=.68, p>.05]$. Likewise, the Americans and Japanese were not significantly different in their average responses toward people with whom they had distant relationships (Items 2, 5, 9, 
12,16 , and 18) $[F(1,86)=.52, p>.05]$. Here, the American average was 3.17 and the Japanese average was 3.36 .

In most of the 16 items, females indicated greater degrees of likelihood to give compliments than males (Table 2). American females had the highest overall average at 5.10, followed by Japanese females at an average of 4.76. American males then followed, with an average 4.30. Japanese males registered lowest at 4.28. The results of a one-way ANOVA indicated that there was a significant group effect among the averages $[F(3,84)=4.09, p<.01]$. Post hoc Tukey tests then revealed that the overall average of American females was significantly different from both that of American males and that of Japanese males (Table 3). On the other hand, no significant average differences were detected between American males and Japanese males, between American males and Japanese females, or between American females and Japanese females.

Table 2. Response Averages Sorted by Gender

\begin{tabular}{ccccc}
\hline Item & AM & AF & JM & JF \\
\hline 1 & 4.68 & 6.50 & 4.64 & 5.91 \\
2 & 3.05 & 3.18 & 3.23 & 2.73 \\
3 & 6.73 & 7.00 & 6.68 & 6.68 \\
5 & 2.55 & 3.27 & 3.45 & 3.50 \\
6 & 6.23 & 6.82 & 4.27 & 5.64 \\
7 & 5.00 & 5.82 & 4.59 & 5.64 \\
8 & 4.57 & 6.00 & 4.59 & 5.45 \\
9 & 3.77 & 3.95 & 3.82 & 3.27 \\
10 & 4.62 & 5.18 & 5.59 & 5.73 \\
11 & 3.05 & 3.41 & 4.45 & 4.73 \\
12 & 2.05 & 2.95 & 3.09 & 3.64 \\
14 & 5.50 & 6.68 & 4.50 & 5.05 \\
15 & 5.91 & 6.32 & 4.50 & 5.68 \\
16 & 2.23 & 3.59 & 2.77 & 3.68 \\
18 & 3.14 & 4.18 & 3.68 & 3.45 \\
20 & 5.68 & 6.77 & 4.64 & 5.36 \\
\hline Overall & 4.30 & 5.10 & 4.28 & 4.76 \\
\hline
\end{tabular}


Table 3. Results of Multiple Comparisons

\begin{tabular}{rcccc}
\hline & AM & AF & JM & JF \\
\hline $\mathrm{AM}$ & & $*$ & n.s. & n.s. \\
$\mathrm{AF}$ & $*$ & & $*$ & n.s. \\
$\mathrm{JM}$ & n.s. & $*$ & & n.s. \\
$\mathrm{JF}$ & n.s. & n.s. & n.s. & \\
\hline${ }^{\mathrm{p}}<.05$ & & & &
\end{tabular}

American and Japanese averages sorted by interlocutors' gender types suggest that in both cultures compliments were most likely to be exchanged between females and least likely to be given from males to males (Table 4). Addressees in questionnaire items 1, 5, 7, 8, 16, 18, and 20 were meant to share respondents' gender. The average of American females for these items was 5.16 and that of Japanese females was 4.71. American male respondents indicated an average of 3.99 and Japanese male respondents 4.05 . The likelihood of compliments occurring in male-to-female and female-to-male interactions, on the other hand, were elicited in Items 2, 3, 9, 10, 11, and 12. In these items, Japanese females indicated an average of 4.64 and American females 4.57. The average of American males was 4.48 whereas that of Japanese males was 4.16.

Table 4. Response Averages Sorted by Interactional Gender Type

\begin{tabular}{ccc}
\hline & Americans & Japanese \\
\hline F-F & 5.16 & 4.71 \\
F-M & 4.57 & 4.64 \\
M-F & 4.48 & 4.16 \\
M-M & 3.99 & 4.05 \\
\hline
\end{tabular}

There were no significant cultural differences in the likelihood of praising others of the same gender. In other words, the female-female and male-male interactions in questionnaire items $1,5,7,8,16,18$, and 20 did not indicate significant differences in average ratings between Americans and Japanese. In these items, American females as a whole expressed a little more willingness to give compliments than their 
Japanese female counterparts, although their averages of 5.16 and 4.71 , respectively, were not statistically different $[F(1,42)=2.48, p>.05]$. Similarly, in male-male compliment-giving scenarios, there was little difference between the American and Japanese male group averages, that is, 3.99 and 4.05 , respectively $[F(1,42)=.03, p>.05]$.

Likewise, in male-to-female interactions as well as in female-to-male ones, there were no significant cultural differences. First, American male and Japanese male groups revealed no significant difference in addressing females, with their averages of 4.16 and 4.48 , respectively $[F(1,42)$ $=1.02, p>.05]$. Toward male addressees, in turn, American and Japanese females averaged 4.57 and 4.64, respectively, which revealed no significant difference either $[F(1,42)=.07, p>.05]$.

General ideas that people hold about compliments were then examined. Table 5 presents frequencies and averages of American and Japanese responses for Items 21 to 29. There were notable differences in answers for at least three items: 23, 27, and 29. For Item 23, "It is easy for me to make small compliments," the majority of Americans in this study chose agree-type responses ("strongly agree" to "agree somewhat"), and their average was 5.39. The Japanese responses, on the other hand, were spread between "strongly agree" and "strongly disagree," with an average of 3.77. For Item 27, "Giving compliments is just a habit for me," the majority of Japanese respondents selected negative responses ( $M=$ $2.41)$, whereas the American responses were varied $(M=4.02)$. Thirdly, for Item 29, American respondents tended to indicate positive attitudes toward the notion that complimenting is an important custom in their own culture $(M=5.36)$. Japanese, on the other hand, tended to chose neutral to negative options $(M=3.11)$.

At the same time, responses to the rest of the items implied that Americans and Japanese held similar beliefs about compliment giving. Both groups tended to think that complimenting makes people happy (Item 21), that it is a good conversation starter (Item 22), and that giving compliments makes them feel good (Item 26). In contrast, both groups responded negatively to the notion that they expected to receive compliments in return (Item 28). Furthermore, their beliefs varied with respect to the notion that they would not give compliments unless they were actually impressed (Item 24), and that complimenting could be an effective strategy to get compliance (Item 25).

Finally, in the open-ended questionnaire item (Item 30), in which participants were asked to comment on when and why they make compliments, only a handful of participants responded in detail. Those in the 
Table 5. American and Japanese Beliefs about Compliment-giving

\begin{tabular}{|c|c|c|c|c|c|c|c|}
\hline 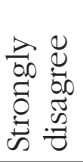 & 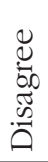 & 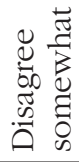 & 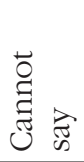 & 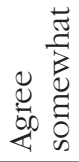 & $\begin{array}{l}0 \\
\stackrel{0}{4} \\
\stackrel{0}{4}\end{array}$ & 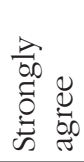 & \\
\hline 1 & 2 & 3 & 4 & 5 & 6 & 7 & Mean \\
\hline
\end{tabular}

21. I compliment someone because I really want to make him/her happy.
A 0
1
10
7
26
9
5.89
J 3
1
7
10
13
9
5.16

22. Complimenting is a good way to start a conversation.
A 20
2
49
18
9
5.45
J 1
0
3
$10 \quad 16$
11
$6 \quad 5.07$

23. It is easy for me to make small compliments.
$\begin{array}{lll}\text { A } & 1 & 1 \\ \text { J } & 4 & 7\end{array}$
43
9
17
9
5.39
$8 \quad 11$
7
43
3.77 (

24. I don't give compliments unless someone really impresses me.
A 26
8
$8 \quad 11$
2
4.11
J 1
8
$5 \quad 10$
7
8
4.39

25. Complimenting is an effective strategey for getting compliance from someone.
A
6
6
9
11
9
0
4.05
J $2 \quad 7$
4
10
13
6
2
4.16

26. I give compliments because it make me feel good.
A 2
21
3
15
12
9
5.25
J 3
3
$12 \quad 12$
6
7
4.66

27. Giving compliments is just a habit for me.
A 6
4
6
8
9
92
4.02
J 11
16
7
9
0
1
0
2.41

28. I give compliments, expecting to receive a compliment in returm.
A 13
15
8
0
4
0
2.34
J 21
13
3
3
3
0
2.02

29. Complimenting is an important custom in our culture.

\begin{tabular}{rrrrrrrrr}
$\mathrm{A}$ & 0 & 0 & 3 & 7 & 13 & 13 & 8 & 5.36 \\
$\mathrm{~J}$ & 8 & 11 & 6 & 12 & 3 & 2 & 2 & 3.11 \\
\hline
\end{tabular}


American group commented: "I compliment when I am in a good mood," "With manipulative intent," "Compliments are a mild form of recognition and appreciation of a person," "I don't give compliments on expensive brand goods," "To impress the opposite sex," and "If someone is feeling down." On the other hand, Japanese comments included: "I give compliments to show politeness," "Complimenting someone makes me feel that I must also endeavor to become a person who deserves a compliment," and "I might give compliments to impress a nearby third person." Other Japanese comments included: "In order to get information on the things that I am praising (clothes, hair salon, etc.)" and "In order to show that I like that person."

\section{Discussion}

Factors such as the gender of both interlocutors, psychological distance, and relative status appear to affect the compliment-giving behavior of Americans and Japanese. The results of this study suggest that compliments are mostly exchanged between people in close relationships. However, detailed analysis suggests a notable difference between American and Japanese compliment-giving behavior. Data from the American students suggest that the closer the relationship, the more likely they were to give compliments. The Japanese respondents, on the other hand, were less likely to praise family members than nonfamily members. This is deeply related to their views of $u c h i$ (inside) and soto (outside). For Japanese, family members are miuchi (insiders), literally flesh and blood, and they are given the permanent status of insiders. Japanese appear to believe that they do not have to give appearance-related compliments to family members in everyday situations, just as they do not compliment their own appearance. Instead, nonfamily members, or outsiders, deserve to receive compliments because Japanese in general believe that outsiders should be treated with a greater degree of politeness. Nevertheless, those outsiders who deserve to receive compliments still have to be perceived as somewhat close. In this study, respondents indicated less likelihood of giving compliments to people who were perceived to be distant. This contradicts Barnlund and Araki's (1985) finding that Japanese exchange compliments less frequently in close relationships than in distant ones. This difference in findings may be due to the fact that the present study distinguished between family members and other people close to the respondents, while the Barnlund and Araki study did not. 
Another notable difference between cultures was revealed by the question regarding whether students would compliment a young instructor they know well (Item 11). The results suggest that American students would refrain from complimenting their instructors, whereas many Japanese might not hesitate to compliment them. It appears that what affected Americans most in deciding whether to give a compliment was the status and power of the addressee. Many Americans in this study seemed to believe that complimenting a person with a higher status would not be appropriate in their culture, perhaps seeing it as a fawning behavior. Knapp et al. (1984) found that compliments were rarely given to higher status addressees (in their corpus of American compliments, only $7 \%$ were given by a lower status speaker, while $71 \%$ were exchanged between people of equal status and 22\% were from higher status to lower status). On the other hand, a more important criterion for Japanese to compliment others (i.e., people other than family members) appears to be psychological closeness to the addressee. Although Japanese students also seemed to be aware that instructors have power in the classroom, psychological closeness appeared to outweigh status issues, especially if a casual atmosphere exists among the interlocutors. However, this Japanese and American difference was found in only one questionnaire item. Future study is thus needed to further explore whether perceived closeness truly overrides status and power in Japanese compliment-giving behaviors.

Female respondents from both cultures appear more likely to offer compliments than males. In particular, there was a significant gender difference among the American respondents. That females are more likely to give compliments than males coincides with the findings of previous research on English compliments (e.g., Knapp et al., 1984). While Japanese females also indicated a higher likelihood to compliment than males, no significant gender difference was found.

Unlike Barnlund and Araki (1985) who found that Americans were far more likely to compliment others than Japanese were, this study did not detect large cultural discrepancies in the respondents' own perceived likelihood to give compliments. In this study, the American and Japanese respondents did not differ in their overall likelihood to compliment others, excluding family members. Significant cultural differences were not detected in any of the four interactional environments either: male to male, female to female, male to female, and female to male. There seem to be several reasons for this. One possible reason lies in the different methodology used. Barnlund and Araki (1985) interviewed their 
American and Japanese participants, and asked them to recall and report when and where they had last given or received a compliment, who the compliment givers and receivers were, and what the appraised attribute was. The authors were interested only in actual compliment giving and -receiving incidents. There were no controls over relationships between speakers and addressees nor were there any control over attributes praised. The scope of the present study, on the other hand, was quite different from their study. Strictly specifying addressees' age range, gender, and occupation, as well as attributes praised and the psychological distance between speakers and hearers, this study aimed to compare the extent to which Americans and Japanese express their willingness to give a compliment. For comparative purposes, the investigator created highly controlled hypothetical situations that participants may or may not encounter in real life. If this study had employed different methods of data collection and analysis, such as methods similar to those used by Barnlund and Araki, different results may well have been yielded. However, the results obtained in this study still imply that there could be fewer cultural differences in compliment giving than suggested by Barnlund and Araki.

The second reason for the fewer discrepancies in the present study may be found in the participants themselves. Barnlund and Araki's article appeared in 1985, and Japanese students may well have changed over the years. Young Japanese today tend to be more open than college-age Japanese of the past, and they express their opinions more freely. Therefore, it is quite possible that university students today would compliment others' appearance more frequently and less reservedly. However, this is highly hypothetical. It should be noted that our Japanese respondents as a whole did not believe that giving compliments is an important custom in Japanese culture, suggesting they still do not exhibit a positive politeness culture, at least in their beliefs concerning the act of giving compliments.

\section{Conclusion}

This study focused on how the American and Japanese likelihood of complimenting others would differ toward addressees of various psychological distances and social statuses. American and Japanese attitudes toward compliments seemed to differ in several ways. First, American respondents indicated that they would be more willing to compliment their own family members than their Japanese counterparts would. The 
Japanese conceptual distinction between uchi (inside) and soto (outside) was pertinent in this. In general, Japanese tend to think that they should be more polite to nonfamily members (outsiders) than to family members (insiders) in their language use, which of course includes the act of complimenting. Secondly, while Americans tended to show reserve in complimenting their instructors, many Japanese indicated that they would not hesitate to do so in this scenario. This Japanese tendency was observed in one specific situation in which the instructor was described as young and to whom the respondent felt psychologically close. Third, the influence of gender difference on the likelihood of complimenting others is greater for Americans than for Japanese. Overall, American females indicated a significantly greater likelihood to give compliments than American males, whereas no significant gender difference was revealed between Japanese males and females. Fourth, while the majority of Americans considered complimenting to be an important American custom and felt it easy to give compliments, Japanese tended not to perceive complimenting as an important part of their culture and indeed felt it somewhat difficult to praise others.

On the other hand, Americans and Japanese perceptions on compliment-giving were similar in several respects. With the exception of family members as addressees in Japanese-speaking situations, the closer the perceived distance toward the interlocutor, the higher the average willingness to compliment in both groups. Respondents from both cultures indicated they were most likely to compliment boyfriends and girlfriends. Their compliment-giving likelihood was also similar in the four gender settings of interactions, (i.e., male to male, female to female, male to female, and female to male). In each of these, there were no significant cultural differences observed. In other words, American and Japanese respondents indicated that they were almost equally willing either to give or refrain from giving compliments to addressees of both genders.

Other findings in this study concerned American and Japanese beliefs about complimenting. Both groups tended to think that a compliment could be a good conversation starter, that giving a compliment would make them feel good, that they would like to make an addressee happy by giving compliments, and that they would not expect to be complimented reciprocally after they compliment someone. Furthermore, both groups held almost neutral attitudes toward the idea that complimenting is an effective means of getting compliance from someone, and both groups indicated that they would not give compliments unless someone really impressed them. 
I would like, in closing, to make some suggestions for EFL teachers in Japan. The Japanese participants in this study expressed a relatively high level of willingness to give compliments whenever they thought it was necessary, a finding I had not anticipated. However, their willingness did not necessarily mean that they would perform this act as frequently as Americans do in that Japanese tended to consider it difficult to give compliments in general. Japanese EFL learners may feel even more difficulty complimenting others in English. Since Americans in this study believed that complimenting is an important custom in the U.S., it would be beneficial to teach how native speakers of English accomplish the speech act of complimenting, perhaps by explicating the three types of formula reported by Manes and Wolfson (1981). Native English speakers, in turn, should be aware that Japanese students might not give compliments even in situations where English speakers would naturally offer compliments. In particular, Japanese might not compliment family members, especially when nonfamily members are present, since nonfamily members are regarded as deserving more polite treatment in all conversational settings.

\section{Acknowledgments}

I would like to express my gratitude to all participants in this study and the two anonymous reviewers of JALT Journal. I would also like to extend to my special thanks to Aya Matsuda and Paul Matsuda for introducing me to their American English-speaking students in the U.S.

Hiroko Matsuura is a professor of English and Communication at Fukushima University. Her research interests include sociolinguistics, interlanguage pragmatics, and language attitude studies.

\section{References}

Bachnik, J. M. (1994). Uchi/soto: Challenging our conceptualizations of self, social order, and language. In J. M. Bachnik \& C. J. Quinn (Eds.), Situated meaning (pp. 3-37). Princeton, NJ: Princeton University Press.

Barnlund, D. C., \& Araki, S. (1985). Intercultural encounters: The management of compliments by Japanese and Americans. Journal of Cross-Cultural Psychology, 16, 9-26.

Brown, P., \& Levinson, S. C. (1987). Politeness: Some universals in language usage. Cambridge: Cambridge University Press. 
Chen, R. (1993). Responding to compliments: A contrastive study of politeness strategies between American English and Chinese speakers. Journal of Pragmatics, 20, 49-75.

Clark, H. H. (1996). Using Language. Cambridge: Cambridge University Press.

Creese, A. (1991). Speech act variation in British and American English. Working Papers in Educational Linguistics, 7, 37-58.

Daikuhara, M. (1986). A study of compliments from a cross-cultural perspective: Japanese vs. American English. Working Papers in Educational Linguistics, 2, 103-133.

Golato, A. (2002). German compliment responses. Journal of Pragmatics, 34, 547-571.

Han, C. (1992). A comparative study of compliment responses: Korean females in Korean interactions and in English interactions. Working Papers in Educational Linguistics, 8, 17-31.

Herbert, R. K. (1989). The ethnography of English compliments and compliment responses: A contrastive sketch. In W. Oleksy (Ed.), Contrastive pragmatics (pp. 3-35). Amsterdam: John Benjamins.

Herbert, R. K. (1990). Sex-based differences in compliment behavior. Language in Society, 19, 201-224.

Herbert, R. K., \& Straight, H. S. (1989). Compliment-rejection versus complimentavoidance: Listener-based versus speaker-based pragmatic strategies. Language and Communication, 9, 35-47.

Holmes, J. (1988). Compliments and compliment responses in New Zealand English. Anthropological Linguistics, 28, 485-507.

Knapp, M. L., Hopper, R., \& Bell, R. A. (1984). Compliments: A descriptive taxonomy. Journal of Communication, 34, 12-31.

Lewandowska-Tomaszczyk, B. (1989). Praising and complimenting. In W. Oleksy (Ed.), Contrastive pragmatics (pp. 73-100). Amsterdam: John Benjamins.

Lorenzo-Dus, N. (2001). Compliment responses among British and Spanish university students: A contrastive study. Journal of Pragmatics, 33, 107-127.

Manes, J., \& Wolfson, N. (1981). The compliment formula. In F. Coulmas (Ed.), Conversational routine: Explorations in standardized communication situations and prepatterned speech (pp. 115-132). The Hague: Mouton Publishers.

Matsuura, H. (2002). A cross-cultural study of compliment responses in American English and Japanese. The Shogaku Ronshu, 71, 1, 53-66.

Matsuura, H. (2004). Exploring compliments in American English and Japanese: A comparative study. The Shogaku Ronshu, 72, 3, 1-12.

Nelson, G. L., Al-Batal, M., \& Echols, E. (1996). Arabic and English compliment responses: Potential for pragmatic failure. Applied Linguistics, 17, 411-432.

Nelson, G. L., El Bakary, W., \& Al Batal, M. (1993). Egyptian and American compliments: A cross-cultural study. International Journal of Intercultural Relations, 17, 293-313. 
Saito, H., \& Beecken, M. (1997). An approach to instruction of pragmatic aspects: Implications of pragmatic transfer by American learners of Japanese. The Modern Language Journal, 81, 363-377.

Wolfson, N. (1983). An empirically based analysis of complimenting in American English. In N. Wolfson \& E. Judd (Eds.), Sociolinguistics and language acquisition (pp. 82-95). Rowley, MA: Newbury House Publishers.

Ylänne-McEwen, V.(1993). Complimenting behavior: A cross-cultural investigation. Journal of Multilingual and Multicultural Development, 14, 499-508.

(Received December 25, 2003; accepted March 4, 2004)

\section{Appendix}

Questionnaire (English version)

\section{Part I}

This is to investigate the likelihood of your giving compliments to a variety of people and in a variety of situations. Please read Situations 1 to 20 and indicate your feeling by choosing a number below.

\section{1-unlikely 2-less likely 3-somewhat less likely 4-not sure} 5-somewhat likely 6-likely 7-highly likely

1. Imagine that you see your close-friend (of the same sex; if you are male, he's a male) on campus. You have noticed that he/she is wearing a new shirt that you think is really nice. After exchanging greetings, what is the likelihood that you might give a compliment about that shirt? Please indicate the likelihood using the scale below.

$\begin{array}{lllllll}1 & 2 & 3 & 4 & 5 & 6 & 7\end{array}$

2. Imagine that you are in class and are sitting next to your classmate (of the opposite sex) you barely know. You saw him/her wearing a famous brand-name cap when he/she came into the classroom. You really like that brand. Indicate the likelihood of giving him/her a compliment about the cap.

3. Imagine that you have a girlfriend/boyfriend. One day you see him/ her, and you notice that he/she has a new haircut, and you think it is nice. Indicate the likelihood of giving him/her a compliment about the haircut.

4. Imagine that your classmate (of the opposite sex) gave a presentation in your seminar class today. Although you barely knew him/her, you thought it was excellent. Indicate the likelihood of giving him/her a compliment about the presentation. 
5. Imagine that you are in class and are sitting next to your classmate (of the same sex) you barely know. You saw him/her wearing expensive brand sunglasses when he/she came into the classroom, and you liked them. Indicate the likelihood of giving him/her a compliment about the sunglasses.

6. Imagine that your mother is wearing a gorgeous dress and pearl necklace for her relative's wedding reception. You think she looks nice. Indicate the likelihood of giving her a compliment about the outfit.

7. Imagine that you belong to a tennis club. Your tennis coach (of the same sex) is in his/her early 30's and is very friendly. You often talk to him/her not only about tennis but also about personal matters. One day you come across him/her on campus, and you notice that he/she is wearing a nice new jacket (or dress). Indicate the likelihood of giving a compliment to him/her after greeting him/her.

8. Imagine that you belong to a chorus club at your school. One day, you see one of the members (of the same sex and younger than you) wearing a nice tie (or brooch). You know him/her well and you really liked the tie (brooch). Indicate the likelihood of making a compliment about it.

9. Imagine that you are a member of the school swim team. One day, you see one of your teammates (of the opposite sex and younger than you) wearing a nice jacket of a famous brand. You barely knew him/her, but you really like that brand. Indicate the likelihood of giving a compliment about the jacket.

10. Imagine that you are a member of the school swim team. One day, you see one of your teammates (of the opposite sex and younger than you) wearing an expensive brand sweater. You know him/her well and you really like that brand. Indicate the likelihood of making a compliment about the sweater.

11. Imagine that you are enrolled in a seminar class. Your instructor (of the opposite sex) is in his/her early 30's and is very friendly, and you have never hesitated to ask him/her questions. One day you come across him/her on campus, and you notice he/she is wearing a nice new jacket (or dress). Indicate the likelihood of giving a compliment to him/her after greeting him/her.

12. Imagine that you are at your academic advisor's (of the opposite sex and in his/her 50's) office to ask questions about your thesis. 
You notice that he/she is wearing a famous brand-name jacket. You barely know him/her personally, but you really like the jacket. Indicate the likelihood of making a compliment about it.

13. Imagine that your classmate (of the opposite sex) played the piano in the school concert, and you happened to be in the audience. Although you barely knew him/her, you thought it was excellent. Indicate the likelihood of giving him/her a compliment when you see him/her after the concert.

14. Imagine that your father is wearing an expensive suit and tie for a relative's wedding reception. You think he looks nice in these. Indicate the likelihood of giving him a compliment about the outfit.

15. Imagine that you have a younger sister (if you are male) or brother (if you are female). Today, she/he had her/his hair cut. Indicate the likelihood of giving her/him a compliment about the new haircut.

16. Imagine that you are at your academic advisor's (of the same sex and in his/her 50's) office to get his/her signature. You notice that he/she is wearing an expensive tie (or scarf) of your favorite brand. You barely know him/her personally, but you really like the tie (or scarf). Indicate the likelihood of making a compliment about it.

17. Imagine that your close friend (of the same sex) and you are in the same seminar class. Today, your friend gave a presentation, and you thought he/she did an excellent job. Indicate the likelihood of giving him/her a compliment about the presentation.

18. Imagine that you belong to a chorus club at your school. One day, you see one of the members (of the same sex and younger than you) wearing a nice-looking pin on the lapel of his/her jacket. You barely knew him/her, but you really like the pin. Indicate the likelihood of giving a compliment about it.

19. Imagine that your close friend (of the same sex) gave an excellent guitar performance in the school concert. You were in the audience and were really impressed. Indicate the likelihood of giving him/her a compliment when you see him/her after the concert.

20. Imagine that you have a younger brother (if you are male) or sister (if you are female). Today, he/she had his/her hair cut. Indicate the likelihood of giving him/her a compliment about the new haircut. 


\section{Part II}

When and why do you think you compliment others? Please read items 21 to 29 and indicate your response by choosing a number below, and briefly write about your idea in item 30.

1-unlikely 2-less likely 3-somewhat less likely 4-not sure 5-somewhat likely 6-likely 7-highly likely

When/Why?

21. I compliment someone because I really want to make him/her happy.

$$
\begin{array}{lllllll}
1 & 2 & 3 & 4 & 5 & 6 & 7
\end{array}
$$

22. Complimenting is a good way to start a conversation.

23. It is easy for me to make small compliments.

24. I don't give compliments unless someone really impresses me.

25. Complimenting is an effective strategy for getting compliance from someone.

26. I give compliments because it makes me feel good.

27. Giving compliments is just a habit for me.

28. I give compliments, expecting to receive a compliment in return.

29. Complimenting is an important custom in our culture.

30. If you come up with some other reasons for giving compliments, please explain briefly.

\section{Personal background}

1. Sex: Male / Female

2. Age: $(\quad)$

3. Major: ( )

4. Native language: ( )

5. Experience of living in a foreign country? : Yes/ No

If yes, when and where?

When: From ( ) years old to ( ) years old

Where: ( 